https://doi.org/10.52240/1857-2367.2020.2(21).43

\title{
SPECII CONDIMENTARE NOI DE INTERES PENTRU REPUBLICA MOLDOVA
}

\author{
Ludmila DOMBROV, Nina CIOCÂRLAN \\ Grădina Botanică Națională (Institut) ,Al. Ciubotaru”, \\ Chișinău, Republica Moldova
}

\begin{abstract}
The paper refers to three spicy and medicinal species (Verbena triphylla L. Hér., Physalis ixocarpa Brot. and Cymbopogon flexuosus (Nees ex Steud.) W. Watson) cultivated and studied in the National Botanical Garden (Institute) "Al. Ciubotaru”. The information about description, uses, essential oil composition and some aspects of their cultivation are given.
\end{abstract}

Key words: spicy plants, Verbena triphylla, Physalis ixocarpa, Cymbopogon flexuosus, utilization

Lucrarea se referă la trei specii condimentare noi (Verbena triphylla L. Hér., Physalis ixocarpa Brot. și Cymbopogon flexuosus (Nees ex Steud.) W. Watson) recunoscute pentru conținutul sporit de uleiuri eterice, vitamine, acizi organici, dar și pentru utilizarea lor în calitate de condiment. Se cultivă și se cercetează în Grădina Botanică Națională (Institut) "Al. Ciubotaru".

Verbena triphylla (sin. Aloysia citriodora Paláu, Aloysia triphylla (L' Hér.) Britton), lămâiță, aparţine familiei Verbenaceae și este originară din America de Sud (Figura 1). Se cultivă pe larg ca plantă medicinală şi aromatică în zonele tropicale şi subtropicale. Uleiul volatil posedă proprietăţi antioxidante, antimicotice, antispasmodice, antiseptice, afrodiziace, digestive, emoliente, hepatice, tonice [2]. În calitate de condiment se utilizează partea aeriană în stare proaspătă la prepararea ceaiului, oțetului, uleiului aromatizat, la asezonarea salatelor. Frunzele tinere pot fi consumate crude drept condiment, din

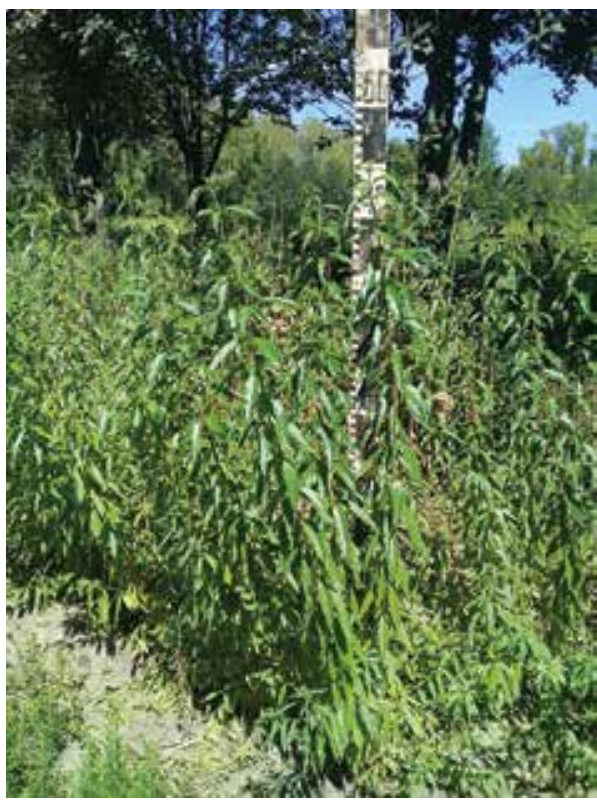

Figura 1. Verbena triphylla ele se prepară siropuri, sorbeturi, sufleuri.

Conţinutul de ulei volatil în frunze și lăstarii uscaţi de lămâiţă cultivată în condițiile Republicii Moldova constituie $0,80 \mathrm{ml} / 100 \mathrm{~g}$ s.u. în faza vegetativă și $0,55 \mathrm{ml} / 100 \mathrm{~g}$ s.u. în faza de îmbobocire. Analiza calitativă a uleiului volatil a determinat prezența a 29 de compuși: limonen $(24,6-25,3 \%)$, geraniol $(14,4-16,7 \%)$, neral $(11,4-13,8 \%)$, cariofilen oxid $(7,8-9,0 \%)$, spatulenol $(4,9-6,6 \%)$. Studiul a indicat apartenenţa speciei $V$. triphylla la chemotipul limonen. Mirosul plăcut de lămâie, conferit de prezenţa geraniolului și neralului o recomandă drept plantă condimentară şi aromatică, iar conţinutul de limonen, care are proprietăţi antibacteriene - ca plantă medicinală. În condițiile noastre $V$. triphylla se comportă ca plantă anuală, fiind specie termofilă și mezofilă, necesită locuri însorite pentru plantare şi 1-2 irigări în perioada 
de vară. Poate fi cultivată în Republica Moldova, cu condiţia dispunerii de încăperi pentru adăpostire în sezonul rece.

Physalis ixocarpa (Tomata mexicană) din familia Solanaceae, este o planta termofilă, anuală, originară din America Centrală și America de Nord, până în Quebec. Florile galbene, situate pe pedunculi scurți în axilele frunzelor, apar din iunie până în septembrie, iar fructele se maturizează din august până în octombrie. Fructul este o bacă galbenă sau violetă cu diametrul de $3-5 \mathrm{~cm}$, cu numeroase semințe mici. Fructele se consumă crude sau fierte. Sunt produse dietetice. Când nu este complet copt, fructul poate fi gătit și utilizat în curry, sosuri, supe, tocănițe etc. Fructul copt este mai dulce și poate fi consumat crud, adăugat în salate sau în plăcinte, conserve etc. Fructele conțin acizi organici, pectine, glucide, vitamina $\mathrm{C}$, caroten, substanțe minerale și taninuri. Conținutul de fitoncide le conferă proprietăți antiseptice. Se consideră, că utilizarea fructelor atenuiază durerile, hemoragiile, stimulează producerea bilei, elimină procesele inflamatorii. Caliciul este toxic. În Grădina Botanică Naţională a fost obținut soiul de Ph. ixocarpa 'Agat GB', care se caracterizează prin fructe cu dimensiuni mai mari și gust deosebit.

Cymbopogon flexuosus (Iarba lămâioasă), din familia Poaceae, originară din India şi Sri Lanka, este o specie perenă cu înălţimea de aproximativ $3 \mathrm{~m}$. Partea aeriană, în stare proaspătă sau uscată, este pe larg utilizată în bucătăria țărilor Asiei de Sud-Est, la condimentarea supelor, fripturii, carry, bucatelor din peşte, fructelor de mare, cărnii. Este apreciată pentru aroma de lămâie pe care o au frunzele, datorită conținutului de ulei volatil, care, de asemenea, conferă speciei proprietăţi antidepresante, sedative, antimicrobiene, antioxidante, antiseptice, astringente, carminative, deodorante, antifungice [1]. Se utilizează în industria de parfumuri, cosmetică (uleiul volatil) și alimentară la producera băuturilor răcoritoare. Plantele în condițiile țării noastre formează o tufă erectă din 15-25 tulpini, cu talia de 95-110 cm. Frunzele lanceolate, de culoare verde intens, au o teacă lungă de $35-40 \mathrm{~cm}$. Fiind specie termofilă, necesită păstrare în încăperi încălzite pe perioada rece a anului.

Cercetările au fost realizate cu suportul ANCD în cadrul proiectului „,Cercetarea și conservarea florei vasculare și macromicobiotei din Republica Moldova”, cifrul 20.80009.7007.22 (contract de finanțare Nr. 71/PS/2020).

\section{BIBLIOGRAFIE}

1. Avoseh, O. et al. Cymbopogon species; ethnopharmacology, phytochemistry and the pharmacological importance // Molecules, 2015, 20, 7438-7453.

2. Bahramsoltani R. et al. Aloysia citriodora Paláu (Lemon verbena): A review of phytochemistry and pharmacology // J Ethnopharmacol., 2018, 222:34-51. 